\title{
Management of elderly people with Stroke: strategies based on action research
}

\author{
Manejo de idosos com Acidente Vascular Cerebral: estratégias a partir de pesquisa-ação
}

Manejo de ancianos con Accidente Cerebrovascular: estrategias a partir de investigación-acción

\section{Luna Vitória Cajé Moura', Larissa Chaves Pedreira', Tânia Maria de Oliva Menezes', Nildete Pereira Gomes', Alyne Henri Motta Coifman', Alice de Andrade Santos'}

' Universidade Federal da Bahia. Salvador, Bahia, Brazil.

\author{
How to cite this article: \\ Moura LVC, Pedreira LC, Menezes TMO, Gomes NP, Coifman AHM, Santos AA. Management
}

of elderly people with Stroke: strategies based on action research. Rev Bras Enferm [Internet]. 2018;71(6):3054-62.

DOI: http://dx.doi.org/10.1590/0034-7167-2017-0915

Submission: 01-11-2018 Approval: 05-25-2018

\begin{abstract}
Objective: To elaborate and implement, through an educational intervention with the nursing team of the Emergency Unit, strategies that contribute to the management of elderly people suspected/affected by Stroke. Method: Action research with eighteen nursing professionals working in the Emergency Unit of a reference hospital. The data were collected through five pedagogical workshops and systematized through the thematic analysis. Results: After a situational analysis and identification of the difficulties in the management of these elderly, a synthesis chart was prepared with strategic actions, responsible professionals and perspectives for implementation in the short, medium and long term. Short-term strategies had, for the most part, immediate implementation; the others were agreed on the need for further implementation. Final considerations: The educational intervention allowed the construction of strategies that were implemented or agreed with the management for later applicability, sensitizing the group regarding the importance of the qualification and prompt care in the management of the elderly suspected/affected by Stroke.
\end{abstract}

Descriptors: Aged; Nursing, Team; Stroke; Emergency Service, Hospital; Education, Continuing.

\section{RESUMO}

Objetivo: Elaborar e implementar, através de intervenção educativa com a equipe de enfermagem da Unidade de Emergência, estratégias que contribuam no manejo de idosos com suspeita/acometidos pelo Acidente Vascular Cerebral. Método: Pesquisa-ação com dezoito profissionais de enfermagem atuantes na Unidade de Emergência de um hospital referência. Os dados foram coletados mediante cinco oficinas pedagógicas e sistematizados através da análise temática. Resultados: Após análise situacional e identificação das dificuldades no manejo destes idosos, foi elaborado um quadro síntese com ações estratégicas, profissionais responsáveis e perspectivas para implementação em curto, médio e longo prazo. Estratégias de curto prazo tiveram, em sua maioria, implementação imediata; as demais foram pactuadas quanto à necessidade de posterior implementação. Considerações finais: A intervenção educativa permitiu construir estratégias que foram implementadas ou pactuadas com a gestão para posterior aplicabilidade, sensibilizando o grupo quanto à importância da qualificação e pronto atendimento no manejo de idosos com suspeita/acometidos pelo Acidente Vascular Cerebral.

Descritores: Idoso; Equipe de Enfermagem; Acidente Vascular Cerebral; Serviço Hospitalar de Emergência; Educação Continuada.

\section{RESUMEN}

Objetivo: Elaborar e implementar, a través de intervención educativa con el grupo de enfermería de la Unidad de Emergencia, estrategias que contribuyan en el manejo de ancianos con sospecha/acometidos por el Accidente Cerebrovascular. Método: Investigación-acción con dieciocho profesionales de enfermería actuantes en la Unidad de Emergencia de un hospital referencia. Los datos fueron recolectados mediante cinco talleres pedagógicos y sistematizados a través del análisis temático. Resultados: Después del análisis situacional e identificación de las dificultades en el manejo de estos ancianos, se elaboró un cuadro síntesis con acciones estratégicas, profesionales responsables y perspectivas para implementación a corto, mediano y largo plazo. Las estrategias a corto plazo tuvieron, en su mayoría, implementación inmediata; las demás fueron pactadas en cuanto a la 
necesidad de posterior implementación. Consideraciónes finales: La intervención educativa permitió construir estrategias que fueron implementadas o pactadas con la gestión para posterior aplicabilidad, sensibilizando al grupo en cuanto a la importancia de la calificación y pronta atención en el manejo de ancianos con sospecha/acometidos por el Accidente Cerebrovascular.

Descriptores: Anciano; Grupo de Enfermería; Accidente Cerebrovascular; Servicio de Urgencia em Hospital; Educación Continua.

\section{CORRESPONDING AUTHOR Alyne Henri Motta Coifman E-mail: alymotta@yahoo.com.br}

\section{INTRODUCTION}

Stroke reaches about 16 million people annually in the world and 6 million people die ${ }^{(1)}$. In Brazil, this condition represents a high index of hospital morbidity and mortality in elderly people, with an increase in hospitalization time and, consequently, high costs to the health system ${ }^{(2)}$.

It is estimated that the minority of people affected by Stroke can reach the Emergency Unit (EU) in the first hours after the injury, in time to receive the benefit of reperfusion therapy or control of intracerebral hemorrhage, which hinders the therapeutic intervention necessary, and may lead to increased severity ${ }^{(3)}$.

Early detection of signs and symptoms, together with rapid and effective management and referral, are necessary for a favorable clinical outcome ${ }^{(4)}$. The target time, considered as a therapeutic window, is up to four and a half hours in situations of Ischemic Stroke, when the effectiveness of cerebral reperfusion is greater ${ }^{(5)}$. In the cases of hemorrhagic or Ischemic Stroke outside the therapeutic window, agile and effective care is also important to control/avoid possible complications.

The EU hospital is an important gateway for the user in any age group, for access to high complexity in the Brazilian Health System (SUS - Sistema Único de Saúde), and is still used inappropriately as an alternative for primary care ${ }^{(6)}$. However, with the aging population, the EU, especially with a clinical care profile, are increasingly being sought by older people, mainly due to the acute situation. An international study revealed that the use of emergency services by elderly people varies between 12 and $21 \%$ of the total number of visits ${ }^{(7)}$. At the national level, there were almost 9 million emergency hospital admissions funded by SUS in 2013, 23\% of which were individuals aged 60 years or above ${ }^{(8)}$.

Older people have different needs compared to younger people, due to the high prevalence of physical, cognitive and complex social circumstances ${ }^{(9)}$. In addition, they are frequently and acutely more $\mathrm{ill}^{(10)}$, more likely to have a long stay in the $\mathrm{EU}^{(11)}$ and remain hospitalized after initial care in this unit ${ }^{(12)}$.

Thus, the health professionals involved, among them the nurse and his/her team, need to be able to offer specialized and humanized care, from the hospital's entrance door to the end, and in Stroke cases, this can be in the ward, Stroke unit (Stroke-U) in the Intensive Care Unit (ICU), or at home.

Based on the experience with the Work Education Program (PET - Programa de Educação pelo Trabalho) Urgency and Emergency Care Networks funded by the Brazilian Ministry of Health (Ministério da Saúde) between 2013 and 2015 in the EU of a reference hospital for Stroke in the state of Bahia, the management and referral of elderly people suspected of being affected by Stroke by the nursing team was inadequate.
The large size of the hospital, coupled with the large contingent of patients, mostly elderly, and the small number of professionals, caused a delay in establishing diagnostic and therapeutic actions, causing an extension of the waiting time of these people, before and after the Embracement with Evaluation and Classification of Risk (EECR), in addition to the delay in the referrals of those already diagnosed. Also, older people outside the therapeutic window were slow to be assisted in their needs, which put them at risk for adverse events and clinical destabilization.

Therefore, it was intended, through an educational intervention with the nursing team, to improve the management and referral of suspect/affected elderly people by Stroke in the EU, in order to minimize the occurrence of sequel and adverse events.

Professionals of the nursing team work directly in the care of the elderly in the EU since the EECR and need to be qualified for this care. In this sense, studies that applied educational interventions with health professionals showed that these promoted personal and professional growth, and raised self-esteem, improving clinical practice ${ }^{(12-13)}$.

\section{OBJECTIVE}

To elaborate and implement, through an educational intervention with the nursing team of the Emergency Unit, strategies that contribute to the management of elderly people suspected/ affected by Stroke.

\section{METHOD}

\section{Ethical aspects}

The matrix project was submitted and approved by the Research Ethics Committee of the Nursing School of the Universidade Federal da Bahia; and to carry out the research of which this article is a cut, an amendment was made to the matrix project, approved by the referent Committee. Institutional authorization was also requested for the collection of data, besides the acceptance of voluntary participation with signing of the Informed Consent Term.

\section{Type of study}

This article is a cross-section of the master's research "Manejo e encaminhamento do idoso com acidente cerebrovascular na emergência: oficinas com a equipe de enfermagem", linked to the matrix project: Reception and care in the Emergency Unit, fruit of PET Emergency Care Networks and Emergency.

We used Action Research (AR), a strategy of research of social and critical origin and empirical basis, that aims to promote modifications in the reality in which the participants live, with 
a wide and explicit interaction between researchers and people involved in the situation under investigation ${ }^{(14)}$.

The AR process used the following dynamic, cyclical and dialogical phases: situational diagnosis, planning, implementation of activities and evaluation ${ }^{(14-15)}$. In the cut on screen the result of the planning, implementation and evaluation of the proposals of actions, produced in the pedagogical workshops will be presented.

Educational interventions through pedagogical workshops, because of their reflexive and dialogic essence, stimulate reflection and favor the participation of the individuals involved, often offering immediate evidence as research results, also contributing to pertinent methodological adjustments ${ }^{(16)}$. They can be used in qualitative research as a strategic approach in the construction of a space for the exercise of critical attitude, and it has as objective to subsidize those involved in the systematization and exchange of knowledge ${ }^{(17)}$.

\section{Study setting}

It was performed in the EU of a public General Hospital $(\mathrm{GH})$, reference in Stroke in the state of Bahia, benefited by the federal "SOS emergências" program ${ }^{(18)}$. The EU works with EECR and uses the Manchester protocol, prioritizing care according to severity level ${ }^{(19)}$. In addition, it has a specific unit to serve people affected by Stroke (Stroke-U).

\section{Study participants}

Participants were 18 professionals (10 nurses and 05 nursing technicians from the EU, 1 nurse and 2 nursing technicians from Stroke- U). These professionals met the inclusion criteria: working in the EU or Stroke- $U$ of the $\mathrm{GH}$ and being present in at least two pedagogical workshops.

Prior to the execution of the workshops, the project was presented to the Medical Board, the Nursing Board and the EU coordination of the $\mathrm{GH}$. In this opportunity, it was possible to discuss the feasibility of the research in the locality and to know the demands of the UE related to the management and the referral, by the nursing team, of the elderly suspected/affected by Stroke. The managers agreed to allow a space in the $\mathrm{GH}$ and the scheduling of the participants so that they could attend the workshops outside the working hours.

\section{Collection and organization of data}

The data collection period occurred from February to August 2016. In the months of February to April, there were visits to observe and approach the field, from May to August, the realization of the pedagogical workshops.

Prior to the start of the data collection, the e-mail and mobile contacts of the professionals working in the EU and Stroke- $U$ were made available for the invitation letter to be distributed, presenting the research project, as well as guidelines on the form of participation in the moments of AR. In this way, it was possible to identify the interested parties and to provide, to the Nursing coordination, a nominal relation of these, for viability of the workload and scale adjustments.

The observational moment, which made up the diagnostic phase, made it possible to understand the dynamics of the EU, the management and referral of elderly people suspected of being affected by Stroke, as well as making initial contact with professionals, explaining and inviting them to participate in the research.

The educational activity occurred during the meetings with the participants, through a test workshop and four pedagogical workshops. For the workshops, the main researcher had the participation of a team of five students, scholars and volunteers, linked to the Center for Studies and Research of the Elderly (NESPI - Núcleo de Estudos e Pesquisas do Idoso), responsible for providing logistical support.

The test workshop and the first pedagogical workshop made it possible to understand the nursing professionals' knowledge regarding the detection of signs and symptoms of Stroke, and how the management and referral of elderly people served suspected/affected by this problem in the EU. As a final product, participants produced a flowchart that exemplified all service.

In the second pedagogical workshop, participants identified the intervening factors in the management and referral of these people, and produced records with the factors that contributed in a positive and negative way in this process.

In the third pedagogical workshop, the action proposal was produced. For its implementation, a clinical case with guiding questions was initially presented to the participants: What do you think could be done to improve the management and referral of suspected/affected elderly people to Stroke in this EU? How can you, the EU nursing professional, help in the proper management of Stroke suspected/affected elderly people at the institution? How can you, the EU nursing professional, assist in the appropriate referral of suspect/affected elderly people to Stroke?

As a product of this discussion, a framework was constructed with the intervening factors identified in the second workshop, the proposed action to resolve such factors, the identification of those directly and indirectly responsible for solving or minimizing the problems detected, and whether the resoluteness would occur in the short, medium or long term. The collective dialogue, mediated by the researcher, allowed discussing the planned and agreed proposal. It was agreed among the participants that the proposal would be presented to the EU nursing coordinator, so that it could issue an opinion on the agreed actions.

After thirty days, the fourth pedagogical workshop was held, which made it possible to discuss the referral of the proposed activities, and to evaluate the implementation of those established to be carried out in the short term, as agreed.

Participants were identified with a badge (Nur 1, 2, 3 ... or Nur. tec 1, 2, 3 ...). During the workshops, the statements were recorded with permission and later transcribed. The data were submitted to the thematic analysis of content ${ }^{(20)}$, following the steps of pre-analysis, material exploration, treatment of results and interpretation. In this way, a qualitative analysis of the discussions was obtained, corroborating in the form of implementation and evaluation of the proposed actions. In addition, all the participants' output during the workshops was organized in charts.

After a month of the fourth workshop, the researchers visited the HG to verify, through a meeting with the EU nursing coordinator, the effectiveness of the proposals, as well as their implementation. Subsequently, two meetings were held in the two subsequent months, to continue their follow-up.

Proposals to be implemented in the short term were those that could be implemented immediately; in the medium term, 
those possible to be implemented or started up to thirty days after the fourth workshop; and in the long term, proposals that depended on joints outside the context of the hospital.

\section{RESULTS}

The observational moment and the educational intervention allowed to identify structural, organizational and managerial aspects that contributed to difficult the management and the referral of the elderly suspected/affected by Stroke in the unit.

Given the problems identified, it was possible to propose actions in the short, medium and long term; identify those responsible for these actions, and evaluate the results of these actions, in the unit. The evaluation of the results was done through the last workshop, through the reports of the participating professionals and visits to the unit, which occurred one month after the last workshop, and in the following two months, when the nursing coordination provided an opinion describing the result of the proposed actions (Chart 1, 2 and 3).
In the short term, the actions were, for the most part, forwarded, such as the preparation of the instrument for the check list of materials and educational material, made available in the unit; TV acquisition to the waiting room and agreement with the communication adviser about the availability of Stroke content on this TV. The acquisition of multi-parameter monitoring equipment was also scored by coordination as an ongoing activity. Actions in the medium term were related to the training of human resources, personnel sizing and the need to value self-care by elderly users.

Due to the fact that they presented themselves as implementation actions in the medium term, their results were not yet verifiable, although the conditions for their implementation had already been initiated, according to the opinion of the Nursing Coordination.

The actions identified as possible to resolve in the long term were related to the fragility of the health care network and in the actions of promotion, prevention and rehabilitation of suspected/affected users by Stroke.

Chart 1 - Short-term proposals and actions of the Nursing Coordination of the State University, Salvador, Bahia, Brazil, 2016

\begin{tabular}{|c|c|c|c|}
\hline Intervening Factors & Formulated actions & Responsibles & Opinion of the Nursing Coordination \\
\hline $\begin{array}{l}\text { Insufficient multi-parameter } \\
\text { monitoring equipment. }\end{array}$ & $\begin{array}{l}\text { - To notify the termination/ } \\
\text { breakdown of the equipment to the } \\
\text { maintenance sector. } \\
\text { - To acquire new materials. } \\
\text { - To create daily checklist of } \\
\text { materials for checking vital signs. }\end{array}$ & $\begin{array}{l}\text {-Nursing team } \\
\text {-Nursing } \\
\text { Coordination of } \\
\text { the EU }\end{array}$ & $\begin{array}{c}\text { - The checklist for checking the materials } \\
\text { at the end of each shift was developed and } \\
\text { implemented. } \\
\text { - To clarify to the nursing team the flow to be } \\
\text { followed in case of break/lack of material. } \\
\text { - To request hospital acquisition of } \\
\text { multiparametric monitors. }\end{array}$ \\
\hline $\begin{array}{l}\text { Difficulty in identifying } \\
\text { people affected by Stroke } \\
\text { due to the diseases that } \\
\text { mimic this disease. }\end{array}$ & $\begin{array}{l}\text { - To construct educational material } \\
\text { and make it available in strategic } \\
\text { locations in the EU. }\end{array}$ & $\begin{array}{l}\text {-Nursing } \\
\text { Coordination of } \\
\text { the EU } \\
\text { - Research } \\
\text { Support Team }\end{array}$ & $\begin{array}{c}\text { - Educational material already prepared and } \\
\text { printed, awaiting the availability of this in the } \\
\text { units. }\end{array}$ \\
\hline $\begin{array}{l}\text { Poor accommodation in the } \\
\text { beds. }\end{array}$ & $\begin{array}{l}\text { - To install Pyramidal Foam } \\
\text { Mattress in the bed when the } \\
\text { elderly person is admitted. } \\
\text { - To inspect the skin daily, } \\
\text { intervening as needed. } \\
\text { - To guide the family to assist in } \\
\text { the daily inspection of the skin, } \\
\text { communicating some abnormality. }\end{array}$ & $\begin{array}{l}\text { Nursing team of } \\
\text { the EU }\end{array}$ & $\begin{array}{l}\text { - To discuss with the care team the } \\
\text { availability of the Pyramidal Foam Mattress, } \\
\text { and how to proceed with the request. }\end{array}$ \\
\hline $\begin{array}{l}\text { Precarious periodic } \\
\text { evaluation in the waiting } \\
\text { room, elderly people } \\
\text { outside therapeutic } \\
\text { window. }\end{array}$ & $\begin{array}{l}\text { - To scale nursing technician in } \\
\text { the waiting room. } \\
\text { - To check vital signs at least } 6 / 6 \mathrm{~h} \text {. }\end{array}$ & $\begin{array}{l}\text {-Nursing } \\
\text { Technicians } \\
\text {-Nursing } \\
\text { Coordination } \\
\text { of the EU }\end{array}$ & $\begin{array}{c}\text { - Not feasible action in short term, due to the } \\
\text { large number of patients in the EU, and the } \\
\text { limitation of professionals. }\end{array}$ \\
\hline $\begin{array}{l}\text { Absence of food for the } \\
\text { elderly in the EU waiting } \\
\text { room. }\end{array}$ & $\begin{array}{c}\text { - To discuss with the nutrition } \\
\text { team about the feasibility of } \\
\text { feeding the elderly patients in the } \\
\text { waiting room. }\end{array}$ & $\begin{array}{l}\text {-Nursing } \\
\text { Coordination of } \\
\text { the EU }\end{array}$ & $\begin{array}{l}\text { - The nutrition service indicated that this } \\
\text { action is feasible only in the long term. }\end{array}$ \\
\hline
\end{tabular}

To be continued 


\begin{tabular}{|c|c|c|c|}
\hline Intervening Factors & Formulated actions & Responsibles & Opinion of the Nursing Coordination \\
\hline $\begin{array}{l}\text { Unknowing the elderly } \\
\text { and their relatives about } \\
\text { the signs and symptoms of } \\
\text { Stroke. }\end{array}$ & $\begin{array}{l}\text { - To perform Health Education } \\
\text { activities in the waiting room. } \\
\text { - To deploy TV in the waiting } \\
\text { room, with health information and } \\
\text { hospital service profile. }\end{array}$ & $\begin{array}{c}\text { - Permanent } \\
\text { Education } \\
\text { Sector } \\
\text { - Hospital } \\
\text { managers and } \\
\text { nursing director }\end{array}$ & $\begin{array}{c}\text {-It will be discussed with the Permanent } \\
\text { Education team, the creation of posters with } \\
\text { educational material, for presentation in the } \\
\text { waiting room. } \\
\text { - The TV was bought and installed in the } \\
\text { waiting room. } \\
\text { - The personnel of the hospital's } \\
\text { communication department will make } \\
\text { available exhibition material on TV, on topics } \\
\text { related to Stroke, among other things. }\end{array}$ \\
\hline
\end{tabular}

Chart 2 - Medium-term proposals for actions and opinion of the Nursing Coordination of the State University, Salvador, Bahia, Brazil, 2016

\begin{tabular}{|c|c|c|c|}
\hline Interveining factors & Formulated actions & Responsibles & Opinion of the Nursing Coordination \\
\hline $\begin{array}{l}\text { Unpreparedness of } \\
\text { bioimaging and EU } \\
\text { professionals in patient } \\
\text { management and } \\
\text { prioritization. }\end{array}$ & $\begin{array}{l}\text { - To conduct Stroke training for } \\
\text { bioimaging and EU professionals. }\end{array}$ & $\begin{array}{l}\text { - The Stroke- U } \\
\text { and Permanent } \\
\text { Education Sector of } \\
\text { the Hospital }\end{array}$ & $\begin{array}{c}\text { - The Permanent Education sector of } \\
\text { the hospital was informed about the } \\
\text { need for training of EU professionals } \\
\text { and bioimaging. }\end{array}$ \\
\hline $\begin{array}{l}\text { Insufficient sizing of } \\
\text { professionals. }\end{array}$ & $\begin{array}{c}\text { - To daily size technical professionals } \\
\text { according to clinical criteria and level } \\
\text { of care complexity. }\end{array}$ & - Nurses of the EU & $\begin{array}{c}\text { - The nurses were advised on the } \\
\text { need to enable the sizing according to } \\
\text { demand. }\end{array}$ \\
\hline $\begin{array}{l}\text { Elderly users with high } \\
\text { dependence for care. }\end{array}$ & $\begin{array}{l}\text { - To carry out Health Education activities } \\
\text { for patients and caregivers, emphasizing } \\
\text { the importance of stimulating self- } \\
\text { care and support in the process of } \\
\text { hospitalization and discharge. }\end{array}$ & $\begin{array}{l}\text { - Nurses and } \\
\text { nursing technicians } \\
\text { of the EU }\end{array}$ & - Long-term activity. \\
\hline
\end{tabular}

Chart 3 - Long-term action proposals and opinion of the Nursing Coordination of the State University, Salvador, Bahia, Brazil, 2016

\begin{tabular}{|c|c|c|c|}
\hline Problems identified & Formulated actions & Responsibles & Opinion of the Nursing Coordination of the EU \\
\hline $\begin{array}{l}\text { Overcrowding of the } \\
\text { EU with low complexity } \\
\text { patients. }\end{array}$ & $\begin{array}{l}\text { - Regulation of patients for } \\
\text { support units } \\
\text { - Medical reassessment in a } \\
\text { timely manner }\end{array}$ & $\begin{array}{l}\text { - Public managers } \\
\text { - Medical Board }\end{array}$ & $\begin{array}{l}\text { - Agree with the need, but it goes beyond the } \\
\text { sphere of the hospital. }\end{array}$ \\
\hline Insufficient human resource. & - Hiring new professionals & $\begin{array}{l}\text { - Hospital Board, } \\
\text { Nursing Board }\end{array}$ & $\begin{array}{l}\text { - Agree with need, however it goes beyond the } \\
\text { sphere of the hospital. }\end{array}$ \\
\hline
\end{tabular}

The activities proposed for long-term implementation are, for the most part, dependent on support of public managers, and their immediate resolution is not possible. Despite being difficult to modify factors, nursing professionals perceived the need to punctuate the existence of the problem and materialize possible actions that would modify/minimize such reality.

\section{DISCUSSION}

The educational intervention revealed, among other aspects, the importance of the Permanent Education in health to improve the knowledge and the interventions of the professionals towards the elderly person. In Brazil, the training and the Permanent Education of health professionals of SUS in relation to the elderly is a priority. In this sense, strategic actions to strengthen knowledge in the area of Aging and Elderly Health are necessary, contemplating the specific contents of the repercussions of the process of population aging for individual health and for the management of health services ${ }^{(21)}$.

In the EU setting, a study carried out with emergent nurses in the state of Bahia revealed their concern about the inclusion of Permanent Education in the emergency and emergency service, 
due to the specialty and the need for constant updating of this sector. Permanent Education, through motivating initiatives, enables the improvement of the practices of health professionals and the improvement of knowledge and skills ${ }^{(22)}$.

Thus, the participants of the pedagogical workshops emphasized the need to strengthen this strategy, capable of promoting improvements in care for the elderly.

Participants indicated that the knowledge of the EU nursing team regarding the peculiarities of elder care with Stroke was fragile. In addition, the fragility in knowledge also led to the non-prioritization of bioimaging exams for the continuation of therapy, and negligence regarding important care for this age group. Thus, educational interventions in action research allowed professionals to reflect on their professional practice, share knowledge and doubts about appropriate behavior and mobilize to improve the situation identified.

Regarding proposed actions to be instituted in the unit in the short, medium and long term, these depend on attitudinal, professional and organizational changes. Some of these were highlighted in the participants' discourses during the workshops, such as the need to train professionals, Permanent Education actions, Health Education, and to resize personnel in the unit.

It is necessary to plan the EU to care for the elderly, training professionals and using approaches that qualify care, including geriatric assessment with specific protocols and functional neurocognitive evaluation. Geriatric assessment is essential for the identification of risks, care planning, treatment effectiveness, recovery and orientation of discharge plan $^{(23)}$.

In addition, it is necessary to requalify the physical environment and concentrate resources and training in common diagnoses for this age group, with self-management of acute exacerbations of cardiovascular and respiratory diseases ${ }^{(24-25)}$.

In this sense, the group of participants was sensitized to the need to improve the care environment, planning actions related to skin protection with the use of Pyramidal Foam Mattresses that, although not gold standard to avoid skin injuries ${ }^{(26)}$, is what is available for use in the industry. The professionals pointed out that structural problems also interfere with other nursing care such as hygiene and comfort. Also, there was mobilization regarding the maintenance and provision of equipment to verify the vital data, with the creation of daily check list of the materials used, aiming to give more agility the identification of the lack of these, and consequent replacement.

Another aspect discussed by the group was the need for Health Education for elderly users and their caregivers, and proposed activities that focused on the importance of stimulating self-care and the support of caregivers in the hospitalization and discharge process; performing activities in the waiting room, and placing a television set in this room with health information.

In the EU, priorities should be established in conjunction with the elderly and their family, involving them in the care process $^{(23)}$. The lack of information from the elderly and family members regarding care, treatment and education for discharge contributes to the sensation of loss of control, independence and also return to the emergency service ${ }^{(27-29)}$.

In this aspect, the nursing team has a relevant role, either in the instruction of patients and the family on the maintenance of home care, the stimulation of self-care activities, as tolerated by the patient, as well as guide how to deal with conflicts and fears arising from the health-disease process ${ }^{(30)}$.

An important initiative in the care of the elderly, which highlights the role of nurses in improving the care and health care of these people in the EU was developed by Canadian nurses, who proposed a comprehensive theoretical model to promote the quality of care, of elderly-friend emergency services. The "elderly-friend" care model is based on four central dimensions, involving the vulnerabilities of the elderly: social climate, policies and procedures, systems and processes of care and physical environment ${ }^{(27)}$.

These dimensions can be pointed out by the professionals participating in the screen study. The dimension of the social climate can be observed in actions such as carrying out Health Education activities with the companions and the elderly, supporting family members in the process of hospitalization and discharge of the elderly, that is, actions that contribute to the involvement of the team in the process of care and recovery, and promote their interaction with the elderly and their caregivers.

Policies and procedures describe each institution's policies and policies. Care systems and processes are related to the organization and delivery of clinical care in the EU, access to best health practices and partnerships between institutions and communities $^{(27)}$. These two dimensions are contemplated in the participants' proposals to establish a dialogue with the nutrition team about the feasibility of feeding the elderly who are waiting in the waiting room, regulating patients for support units, and scheduling the daily distribution of technicians, considering the clinical criteria and level of care complexity.

Interventions, such as the implantation of TV in the waiting room, with information on health and hospital care profile, installation of the Pyramidal Foam Mattress in the bed as soon as the elderly person is admitted to the unit and purchase of new materials to check the vital signs, are congruent with the size of the physical environment and reflect on the safety, comfort, and maintenance of the functional abilities of the elderly.

Therefore, it is understood that the participants understand that their interventions need to address several scopes for the optimization of care for the elderly. However, for efficient, longitudinal care, with continuity and coordination of care, it is also necessary to allocate more resources or personnel to the $\mathrm{EU}^{(31)}$. Co-ordinated care delivery would facilitate the rapid referral of Stroke's suspected elderly people to the start of appropriate therapy and reduce their exposure to the risks of adverse events, minimizing length of stay in the EU, and promoting skilled care and focused on their needs during hospitalization and preparation for discharge.

The allocation of resources and personnel was one of the proposals made by the group, but that does not depend only on the hospital, being an initiative to be implemented in the long term. A study carried out in the EU also points to the workload of nursing professionals, however, recognizing that some actions are outside their governance ${ }^{(32)}$. However, in order to try to alleviate this situation, the group proposed to raise awareness of the nursing team regarding the care of the elderly, taking into account their demands, avoiding that, especially those outside the therapeutic window, stay without periodic evaluation. 
An important strategy that contributes to the maintenance of the assessment of users awaiting care in the $\mathrm{EU}$ is the provision of a professional in the waiting room. In this regard, several initiatives have been developed that incorporate a health professional in waiting rooms, to evaluate and initiate interventions early, decrease waiting times, detect patient deterioration and improve communication ${ }^{(33)}$. However, the literature does not yet provide subsidies for the evaluation of the impact of these professionals on the care of these patients in the Emergency Unit.

Therefore, the solidification of a proposal for the appropriate management and referral of elderly people suspected/affected by Stroke in the EU requires, in addition to local and attitudinal initiatives, the public strengthening of Health Care Networks. These, in theory, are configured as integrated systems, which aim to pay attention to health in the right place, at the right time, with the right quality, at the right cost and with sanitary and economic responsibility by an attached population ${ }^{(34)}$.

It is necessary to know the path of the elderly person in a network, to clarify the care process destined for him, with his peculiarities and unevenness, thus enabling, in this way, to assist in decision making in the daily routine of health services, embodying care, reducing factors associated with the morbidities, instrumentalizing services for the development of comprehensive care to this population ${ }^{(35)}$.

Also, the multidisciplinary team should work collaboratively to offer individualized care to the elderly. Integrated EU action offers healthcare institutions enormous benefits for patients, families and health services, allowing the functioning of this integrated component of a health network ${ }^{(35)}$.

Therefore, the integrated action in network, associated with the strengthening of internal policies that stimulate actions of Permanent Education in Health and Health Education, contribute to the qualified care for the elderly person. It is therefore necessary to raise the profile of the issue and raise awareness among health managers and professionals, so that changes can be made to better serve the elderly, as the EU overcrowding ${ }^{(32)}$, its personnel deficit ${ }^{(31)}$ and the increase in the number of elderly patients in this is a worldwide reality ${ }^{(7)}$.

\section{Study limitations}

The limitations of the study were the absences of professionals in some workshops, which reduced the number of the sample; besides the short time for visualizing the results and monitoring the activities in the medium and long term. However, such limitations did not influence the quality of the data obtained and the consistency of the findings with published productions on the subject.

Although it was not possible to evaluate in the study if all the actions established in the opinion of Nursing Coordination were implemented, there was agreement with the nursing management of the hospital so that the actions continued to be implemented even after the end of the research.

\section{Contributions to the sectors of Nursing and Health}

The educational intervention stimulated the implementation of agreed actions and activities previously planned by EU Nursing Coordination. In addition, the participants had a space for collective reflection, discussions and critical analysis of the reality that were inserted, allowing the improvement of technical knowledge and assistance, which are also shared within the work environment with other colleagues and patients.

This report corroborates the national study carried out with nurses in the form of educational workshops, where they point out that care changes occurred from the reflections, were developed during the group workshops and perceived the future impact of this on their unit ${ }^{(36)}$.

In this context and in general in the area of Health, for educational interventions to contribute to the work process, it is necessary that the professional, as a social actor, go in search of the mechanisms that enable the implementation of the activities discussed ${ }^{(37)}$.

Initiatives such as the on-screen study bring contributions that enable changes in health practices through the education of professionals, being an instrument capable of promoting effective transformations in the practice of nursing professionals and the multiprofessional team.

In addition, due to the partnership of the institution with the institution responsible for the development of this study, future research can be carried out, allowing continuous evaluation of medium and long-term actions.

\section{FINAL CONSIDERATIONS}

The educational intervention was carried out in action research, and it was possible to jointly elaborate, implement and evaluate the actions proposed during the workshops, in order to favor the effectiveness in the management and referral in the Emergency Unit of elderly people suspected of being affected by Stroke. The collective construction of proposals and the actions planned and implemented, based on the needs perceived by professionals, and the desire for changes in the improvement of the health care of those who need their care, especially the elderly, enabled the implementation of some actions in the short period, the beginning of others in the medium term and the awakening to a problem to be solved in the long term. Therefore, it serves as a model to be established in other care settings.

\section{REFERENCES}

1. Brasil. Ministério da Saúde. Acidente Vascular Cerebral (AVC)[Internet]. 2012[cited 2017 Dec 06]. Available from: http://www. brasil.gov.br/saude/2012/04/acidente-vascular-cerebral-avc

2. Botelho TS, Machado Neto CD, Araújo FLC, Assis SC. Epidemiology of stroke in Brazil. Temas Saúde[Internet]. 2016[cited 2017 Dec 06];16(2):361-77. Available from: http://temasemsaude.com/wp-content/uploads/2016/08/16221.pdf 
3. Sociedade Brasileira de Cardiologia. I Diretriz de Ressuscitação Cardiopulmonar e Cuidados Cardiovasculares de Emergência da Sociedade Brasileira de Cardiologia[Internet]. 2013[cited 2018 Apr 16];101(2):67. Available from: http://publicacoes.cardiol.br/ consenso/2013/Diretriz_Emergencia.pdf

4. Alves MJ, Silva SPM, Cunha BTM. Ischemic Stroke: an emergency for nursing. Rev Eletrôn Enferm[Internet]. 2013 [cited 2017 Dec 06];4(4):1-15. Available from: http://www.cpgls.pucgoias.edu.br/8mostra/Artigos/SAUDE\%20E\%20BIOLOGICAS/Acidente\%20 Vascular $\%$ 20Cerebral $\% 201$ squ $\%$ C3\%AAmico $\%$ 20uma $\% 20$ emerg $\%$ C3\%AAncia $\% 20$ para $\% 20$ a $\%$ 20enfermagem.pdf

5. Claire L, Bensenine E, Durier J, Daubail B, Giroud M, Quantin C, et al. Hospitalization within the first year after stroke: the Dijon Stroke Registry. Stroke[Internet]. 2015[cited 2017 Dec 06];46:190-6. Available from: https://www.ncbi.nlm.nih.gov/pubmed/25378425

6. Lowthian JA, Smith C, Stoelwinder JU, Smit DV, McNeil JJ, Cameron PA. Why older patients of lower clinical urgency choose to attend the emergency department. Intern Med J[Internet]. 2013[cited 2017 Dec 06];43(1):59-65. Available from: https://www.ncbi. nlm.nih.gov/pubmed/22646852

7. Gruneir A, Silver MJ, Rochon PA. Emergency department use by older adults: a literature review on trends, appropriateness and consequences of unmet health care. Med Care Res Rev[Internet]. 2011[cited 2017 Dec 06];68(2):131-55. Available from: https:// www.ncbi.nlm.nih.gov/pubmed/20829235

8. Brasil. Ministério da Saúde. Datasus. Morbidade hospitalar por local de internação[Internet]. 2014[cited 2017 Dec 06]. Available from: http://tabnet.datasus.gov.br/cgi/tabcgi.exe?sih/ cnv/niuf.def

9. Debra D, Ashley K, Sarah J. Results of a national survey of Australian nurses' practice caring for older people in an emergency department. J Clin Nurs[Internet]. 2016[cited 2017 Dec 06];25:3049-57. Available from: https://www.ncbi.nlm.nih.gov/ pubmed/27528191

10. Biber R, Bail HJ, Sieber C, Weis P, Christ M, Singler K. Correlation between age, emergency department length of stay and hospital admission rate in emergency department patients aged $\geq 70$ years. Gerontol[Internet]. 2013[cited 2017 Dec 06];59(1):17-22. Available from: https://www.ncbi.nlm.nih.gov/pubmed/23128892

11. Lowthian J, Curtis A, Stoelwinder J, McNeil J, Cameron P. Emergency demand and repeat attendances by older patients. Intern Med J[Internet]. 2013[cited 2017 Dec 06];43(5):554-60. Available from: https://www.ncbi.nlm.nih.gov/pubmed/23279076

12. Toniolo F, Nicodemos FM, Santos AS, Busoi ALZ, Malaquias BSS. Health education with older adults: action research with primary care professionals. Rev Bras Enferm[internet]. 2017[cited 2017 Dec 06];70(4):825-32. Available from: http://www.scielo.br/pdf/ reben/v70n4/0034-7167-reben-70-04-0792.pdf

13. Faustino TN, Pedreira LC, Freitas YS, Silva RMO, Amaral JB. Prevention and monitoring of delirium in older adults: an educational intervention. Rev Bras Enferm[Internet]. 2016[cited 2017 Dec 06];69(4):678-85. Available from: https://www.ncbi.nlm.nih.gov/ pubmed/27508479

14. Thiollent MJM. Metodologia da Pesquisa-ação. 18ª ed. São Paulo: Cortez; 2011.

15. Menezes AG, Lezana AGR, Ronconi LFA, Menezes ECO, Melo EM. Action research as strategy to evaluate social innovation: case study of a kindergarten school in Florianópolis. Navus Rev Gestão Tecnol[Internet]. 2016[cited 2017 Dec 06];6(2):93-105. Available from: http://navus.sc.senac.br/index.php/navus/article/view/367

16. Toledo RF, Giatti LL, Jacobi PRA. Action research in interdisciplinary studies: analysis on criteria that can be revealed only through practice. Interface Comun Saúde Educ[Internet]. 2014[cited 2017 Dec 06];18(51):633-46. Available from: http://www.scielo.br/ pdf/icse/v18n51/en_1807-5762-icse-1807-576220140026.pdf

17. Neves ALD, Draganov PB, Sanna MC. Teaching the history of nursing administration: the strategy of construction timeline. Rev Pesqui: Cuid Fundam[Internet]. 2013[cited 2018 Mar 28];6(3):1068-77. Available from: http://www.redalyc.org/pdf/5057/505750623020.pdf

18. Brasil. Ministério da Saúde. Portaria no 1.663, de 6 de agosto de 2012. Programa SOS Emergências no âmbito da Rede de Atenção às Urgências e Emergências[Internet]. 2012[cited 2017 Dec 06]. Available from: http://bvsms.saude.gov.br/bvs/saudelegis/gm/2012/ prt1663_06_08_2012.html

19. Roncalli AA, Oliveira DN. Manchester protocol and user population in the risk assessment: the nurse's view. Rev Baiana Enferm[Internet]. 2017 [cited 2017 Nov 30];31(2). Available from: https://portalseer.ufba.br/index.php/enfermagem/article/download/16949/14511

20. Brasil. Ministério da Saúde. Portaria n 339 de 22 de fevereiro de 2006. Consolidação do SUS e aprova as Diretrizes Operacionais do Pacto pela Saúde[Internet]. 2006[cited 2017 Nov 30]. Available from: http://bvsms.saude.gov.br/bvs/saudelegis/gm/2006/ prt0399_22_02_2006.html

21. Bardin L. Análise de conteúdo. Lisboa: Edições 70; 2011.

22. Coelho GMP, Abib SCV, Lima KSB, Mendes RNC, Santos RAA, Barros AG. Standing in health education: experience of health professionals of pre-hospital care service. Enferm Foco[Internet]. 2013[cited 2017 Dec 06];4(3,4):161-3. Available from: http:// revista.portalcofen.gov.br/index.php/enfermagem/article/view/540

23. Santos MT, Lima MADS, Zucatti PB. Elder-friendly emergency services in Brazil: necessary conditions for care. Rev Esc Enferm USP[Internet]. 2016[cited 2017 Nov 02];50(4):594-601. Available from: http://www.scielo.br/pdf/reeusp/v50n4/0080-6234reeusp-50-04-0594.pdf

24. Bissett M, Cusick A, Lannin NA. Functional assessments utilized in emergency departments: a systematic review. Age Ageing[Internet]. 
2013[cited 2017 Dec 06];42(2):163-72. Available from: https://www.ncbi.nlm.nih.gov/pubmed/23328756

25. Beauchet O, Launay CP, Fantino B, Lerolle N, Maunoury F, Annweiler C. Screening for elderly patients admitted to the emergency department requiring specialized geriatric care. J Emerg Med[Internet]. 2013[cited 2017 Dec 06];45(5):739-45. Available from: https://linkinghub.elsevier.com/retrieve/pii/S0736-4679(13)00203-5

26. Qaseem A, Tanveer PM, Starkey M, Denberg TD. Risk assessment and prevention of pressure ulcers: a clinical practice guideline from the American College of Physicians. Ann Intern Med[Internet]. 2015[cited 2017 Dec 06];162:359-69. Available from: http:// annals.org/aim/fullarticle/2173505/risk-assessment-prevention-pressure-ulcers-clinical-practice-guideline-from-american

27. Boltz M, Parke B, Shuluk J, Capezuti E, Galvin JE. Care of the older adult in the emergency department: nurses views of the pressing issues. Gerontol[Internet]. 2013[cited 2017 Dec 06];53(3):441-53. Available from: https://www.ncbi.nlm.nih.gov/pubmed/23442380

28. Palonen M, Kaunonen M, Helminen M, Astedt-Kurki P. Discharge education for older people and family members in emergency department: across-sectional study. Int Emerg Nurs[Internet]. 2015[cited 2017 Dec 06];23:306-11. Available from: https://www. ncbi.nlm.nih.gov/pubmed/25770988

29. Palonen M, Kaunonen M, Astedt-Kurki P. Family involvement in emergency department discharge education for older people. J Clin Nurs[ Internet]. 2016[cited 2017 Dec 06];25:3333-44. Available from: https://www.ncbi.nlm.nih.gov/pubmed/27218600

30. Paiva RS, Valadares GV. Experiencing the set of circumstances that influence the significance of hospital discharge: nursing study. Esc Anna Nery[Internet]. 2013[ cited 2017 Dec 06];17(2):249-55. Available from: http://www.scielo.br/pdf/ean/v17n2/v17n2a07.pdf

31. Latham LP, Ackroyd-Stolarz S. Emergency department utilization by older adults: a descriptive study. Can Geriatr J[Internet]. 2014[cited 2017 Dec 06];17(4):118. Available from: https:/www.ncbi.nlm.nih.gov/pmc/articles/PMC4244125/

32. Nascimento ERP, Silva SG, Souza BC, Souza DD, Germer Netto A. Environment of a hospital emergency unit for the elderly care: perception of nursing professionals. Esc Anna Nery[Internet]. 2015[cited 2017 Dec 06];19(2):338-42. Available from: http://www. scielo.br/pdf/ean/v19n2/1414-8145-ean-19-02-0338.pdf

33. Mendes EV. As redes de atenção à saúde[Internet]. 2ªed. Brasília: Organização Pan-Americana da Saúde. 2011 [cited 2017 Dec 06]. Available from: http://www.paho.org/bra/index.php?option $=$ com_docman\&view = download\&category_slug = servicos-saude095\&alias $=1402$-as-redes-atencao-a-saude-2a-edicao-2\&Itemid $=965$

34. Santos CTB, Andrade LOM, Silva MJ, Souza MF. Course of the elderly in health care network: a link to be built. Physis Rev Saúde Colet[Internet]. 2016[cited 2017 Dec 06];26(1):45-62. Available from: http://www.scielo.br/pdf/physis/v26n1/0103-7331physis-26-01-00045.pdf

35. Bourton JH, Young J, Bernier CA. The Geriatric ED: structure, patient care, and considerations for the emergency department geriatric unit. Int J Gerontol[ Internet]. 2014[cited 2017 Dec 06];8(2):56-9. Available from: http://www.sciencedirect.com/science/ article/pii/S1873959814000301

36. Both JE, Leite MT, Hildebrandt LM, Beuter M, Muller LA, Linck CDL. Qualification of the nursing team by means of convergent-care research: contributions to the care of the hospitalized elderly person. Esc Anna Nery[Internet]. 2014[cited 2018 Apr 15];18(3):48695. Available from: http://www.scielo.br/pdf/ean/v18n3/en_1414-8145-ean-18-03-0486.pdf

37. Lima VX, Brito MEM. Perceptions of the nursing team about the practice of health education in a center of burn treatment. Rev Bras Queimaduras[Internet]. 2016[cited 2018 Apr 15];15(2):110-5. Available from: http://www.rbqueimaduras.com.br/exportpdf/303/v15n2a09.pdf 